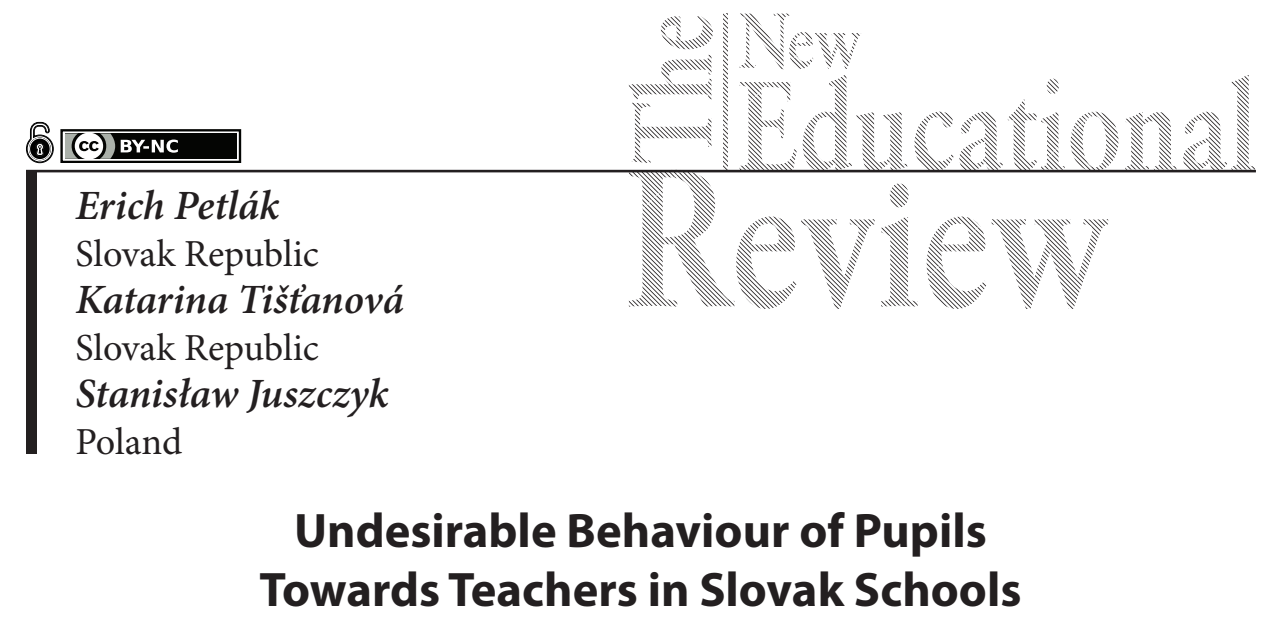

DOI: $10.15804 /$ tner.2019.55.1.14

\begin{abstract}
Recently, a great deal of attention has been paid globally to education of both children and youth. It has been the result of ever-growing requirements of learners' knowledge, as well as educational cultivation of young people. Contemporary society has been witnessing undesirable actions of learners against teachers. That is why the paper discusses learners' interactions with teachers and how they are assessed by teachers. The paper also introduces implications for improving the quality of teachers' interventions in educational processes.
\end{abstract}

Keywords: education, school, behaviour of learners, questionnaire, teachers' views

\title{
Introduction
}

Education of young people is a field of study which has been paid a lot of attention in recent years. At present, unacceptable behaviour of learners at schools is a more serious problem than it used to be. The influence of society and teachers' effort have a great impact on learners. At schools, anywhere in the world, misbehaviour of learners has increased. Speck claims that the cases of misbehaving pupils which were considered to be rare 40 years ago have become common today. Deficiencies in behaviour distinct from the established general standards appear to be tolerated today. (Speck, 1997, p. 39)

Learners' unacceptable behaviour towards teachers is described in literature from different points of view, e.g. "violence against teachers" (Dzuka and Dalbert, 
2007; Chen and Astor, 2009; Mooij, 2011), "bullying and harassment of teachers" (Benefield, 2004), "violence against teachers, psychological and physical" (Melzer, Schubarth, Ehninger, 2011), etc.

\section{The aim of the research}

The presented article deals with learners' behaviour towards their teachers at primary and secondary schools in Slovakia in 2018. Unacceptable behaviour increasingly occurs at schools. This issue is not present only in educational institutions in Slovakia, but also in other countries. For instance, Scheithauer and Bull (2009, p. 13) state that this problem also occurs at German schools, where unacceptable behaviour is not unusual. They add that verbal forms of violence seem to be common.

In the used resources, some similarities could be noticed, as unacceptable behaviour can be direct and indirect (Aluede, 2006; Marini, 2006). Direct forms may be physical (e.g., personal attack, poking, inadequate touching, and unwanted phone calls) or immaterial (Aluede, 2006). The immaterial form could be expressed non-verbally (uncalled-for gestures, mocking, inadequate facial expressions, eye contact, throwing things or damaging them, etc.). Indirect unacceptable behaviour is aimed to hurt a person psychically and emotionally. The learner tries to hide his/ her attempt to hurt the teacher in order not to be punished for the attack. Cases of indirect unacceptable behaviour are usually non-physical forms of non-verbal behaviour which can range from deliberate ignorance or isolation of the teacher (Sullivan et al., 2004), hidden damage or theft of personal possessions (Aluede et al., 2006), to spreading of made-up stories and rumours (James and Lawlor, 2008).

The aim of our study was to find out which cases of unacceptable behaviour of learners towards their teachers occur at schools in Slovakia. According to the result of the study, it will be the prevention of the unacceptable behaviour that will be dealt with in the following stages of the survey (in 2019). The objective was to discover whether the situation in Slovakia is worse, better or similar to the situation abroad.

\section{Characteristics of the research sample}

The choice of the schools was made on purpose - similar number of primary and secondary schools from all regions of Slovakia. However, the sample of teach- 
ers was chosen randomly. A questionnaire was used as the main research tool of this study - 401 teachers. In addition, some of the teachers were interviewed for better and more objective results as they could justify their answers from the questionnaire. 174 teachers were interviewed altogether - they described unacceptable behaviour of their students and their attitude towards those students. The research was based on Helmke (2010), Kindler, Potter, L. (2015), Roewer (2017) and other publications.

Table 1. The research sample of the teachers

\begin{tabular}{lcc}
\hline \multicolumn{1}{c}{ Gender } & $\mathrm{N}$ & $\%$ \\
\hline women & 332 & 89.72 \\
\hline men & 69 & 17.21 \\
\hline Total & 401 & 100.00 \\
\hline
\end{tabular}

Table 2. Differentiation of the teachers according to the educational stage

\begin{tabular}{lcc}
\hline Educational stage & $\mathrm{N}$ & $\%$ \\
\hline primary school & 202 & 50.37 \\
\hline secondary school & 199 & 49.63 \\
\hline Total & 401 & 100.00 \\
\hline
\end{tabular}

The research was carried out in all the regions of Slovakia which may be seen in the following table.

Table 3. Participants according to the Slovak regions

\begin{tabular}{lcc}
\hline \multicolumn{1}{c}{ Region } & $\begin{array}{c}\text { The number of } \\
\text { teachers }\end{array}$ & $\%$ \\
\hline Bratislava & 58 & 14.61 \\
\hline Trnava & 46 & 11.59 \\
\hline Trenčín & 22 & 5.54 \\
\hline Nitra & 60 & 15.11 \\
\hline Žilina & 80 & 20.15 \\
\hline Banská Bystrica & 48 & 12.09 \\
\hline Prešov & 48 & 12.09 \\
\hline Košice & 35 & 8.82 \\
\hline Total & 397 & $\mathbf{1 0 0 . 0 0}$ \\
\hline
\end{tabular}


This research focuses on the unacceptable behaviour of learners as it is currently considered to be rising; learners are thought to have no respect towards their teachers; they are aggressive to their teachers, etc. These attitudes are not described only in our academic literature and in scientific articles, but also in a number of contributions written by foreign authors such as Kindler, Pötter (2015).

\section{Types of misbehaviour}

In this part, all the unacceptable behaviour of learners is described as it was reported by the teachers from their own experience. Some of the teachers did not respond to the questions so the number of the respondents is from 397 to 401 . It was originally planned to carry out analyses of the differences between primary and secondary levels of education, but due to the fact that the results are noticeably alike, the levels were put together to create a complex overview. In addition, no remarkable differences were noticed between the responses of the genders. The most significant aspects have been chosen and are presented as follows:

Table 4. Learners' demonstrative refusal to respond

\begin{tabular}{lcc}
\hline Refusal to respond & $\mathrm{N}$ & $\%$ \\
\hline never & 76 & 19.05 \\
\hline rarely & 196 & 49.62 \\
\hline sometimes & 95 & 23.81 \\
\hline often & 22 & 5.51 \\
\hline normally & 8 & 2.01 \\
\hline Total & 397 & $\mathbf{1 0 0 . 0 0}$ \\
\hline
\end{tabular}

The data in Table 4 is not remarkably pessimistic as the outcome shows that the options of never and rarely amount to $68.67 \%$, which can be considered to be a satisfactory condition. Surely, it would be optimal if the option of never was the highest, but it would be only in the case of regular obeying of the teachers. It must be noted that even the learner's character may cause refusal to obey the teacher. However, the important part is that in this case of refusal, the teacher is not attacked. The teacher rarely noticed refusal to respond with a negative verbal statement. There are 30 learners, $7.52 \%$, who refuse to respond very often. This percentage is not tremendous, but it needs to be focused on in order to eliminate this issue. Similarly to this phenomenon, ignorance is also a type of refusal to respond. It is understood as deliberate conscious disregard of something, deliberate neglect. 
Table 5. Ignoring the teachers by learners

\begin{tabular}{lcc}
\hline Ignoring the teachers & $\mathrm{N}$ & $\%$ \\
\hline never & 110 & 27.50 \\
\hline rarely & 173 & 43.25 \\
\hline sometimes & 72 & 18.00 \\
\hline often & 32 & 8.00 \\
\hline normally & 13 & 3.25 \\
\hline Total & 400 & $\mathbf{1 0 0 . 0 0}$ \\
\hline
\end{tabular}

Findings in this sphere correlate with the previous findings. More than $80 \%$ of the learners do not show negative or ignorant attitudes towards their teachers. The found $11.25 \%$, which is the frequent occurrence of ignorance, is not extremely serious. But obviously, it is a sign for the teachers to be more responsible and provide their students with fewer opportunities for being ignored.

Table 6. Inappropriate verbal statements against the teacher

\begin{tabular}{lcc}
\hline $\begin{array}{c}\text { Inappropriate verbal statements } \\
\text { against the teacher }\end{array}$ & $\mathrm{N}$ & $\%$ \\
\hline never & 124 & 31.08 \\
\hline rarely & 194 & 48.62 \\
\hline sometimes & 70 & 17.54 \\
\hline often & 8 & 2.01 \\
\hline normally & 3 & 0.75 \\
\hline Total & 399 & $\mathbf{1 0 0 . 0 0}$ \\
\hline
\end{tabular}

As inappropriate verbal statements we understand various inappropriate remarks and inappropriate critique of the teacher, using of mocking names, or nicknames, embarrassing and humiliation of the teacher in front of the pupils, in front of other teachers, in public, in the schoolyard, in the corridor, in the classroom, etc. Mocking of the appearance, blackmailing, and threatening are also closely connected to inappropriate verbal statements. It is an effort to prevent the peaceful conduct of the educational process by talking loudly, shouting, vulgar insults, distraction, disregarding of the teacher's commands. Negative verbal statements may be accompanied by non-verbal elements, provocative looking, grimaces, mimicry, gestures, comic movements, or various sound effects: making sounds with their mouths or creating sounds with objects, e.g., toys, mobile phones, banging, knocking on the desk, etc. 
Similarly to the previous findings, it can be concluded that generally, the situation is not that serious while talking about negative verbal comments. However, in those 11 cases (often and normally), i.e., $2.75 \%$ of the learners, it may be considered to be their common behaviour, although it should not be considered to be a standard way of behaviour. If we take into account all the learners and their stratification - excellent, average, and weaker in learning, the social conditions in which some pupils live, etc., then it must be admitted that basically this is not an alarming situation.

Table 7. Threats of damage to a teacher's personal possessions

\begin{tabular}{lcc}
\hline $\begin{array}{c}\text { Threats of damage to a teacher's } \\
\text { personal possessions }\end{array}$ & $\mathrm{N}$ & $\%$ \\
\hline never & 335 & 88.97 \\
\hline rarely & 42 & 10.53 \\
\hline sometimes & 1 & 0.25 \\
\hline often & 1 & 0.25 \\
\hline Total & 379 & $\mathbf{1 0 0 . 0 0}$ \\
\hline
\end{tabular}

Table 8. Cyberbullying of a teacher via the phone or the Internet

\begin{tabular}{lll}
\hline $\begin{array}{c}\text { Cyberbullying of a teacher via } \\
\text { the phone or the Internet }\end{array}$ & $\mathrm{N}$ & $\%$ \\
\hline never & 332 & 83.21 \\
\hline rarely & 54 & 13.53 \\
\hline sometimes & 8 & 2.01 \\
\hline often & 4 & 1.00 \\
\hline normally & 1 & 0.25 \\
\hline Total & 399 & $\mathbf{1 0 0 . 0 0}$ \\
\hline
\end{tabular}

The second factor studied in our research was to investigate cyberbullying as a form of aggression and devaluation via the mobile, the Internet, or social networking sites. The most common occurrences include verbal attacks using a mobile phone or the Internet, threats or intimidation via the mobile phone or the Internet. What can be seen in Table 8 is that $13.53 \%$ of the participants rarely come into contact with cyberbullying via the mobile phone or the Internet. 83.21\% of the participants have never been cyberbullied via the mobile or the Internet, which is an interesting finding because it is believed that cases of cyberbullying have recently risen. Generally, cyberbullying occurs in the relation of "learner $\rightarrow$ learner" or "learner $\leftrightarrow$ learner". 
Table 9. Intentional damage of a teacher's personal belongings at school

\begin{tabular}{lcc}
\hline $\begin{array}{c}\text { Intentional damage of } \\
\text { a teacher's personal } \\
\text { belongings at school }\end{array}$ & $\mathrm{N}$ & $\%$ \\
\hline never & 307 & 76.56 \\
\hline rarely & 69 & 17.21 \\
\hline sometimes & 20 & 4.99 \\
\hline often & 3 & 0.75 \\
\hline normally & 2 & 0.50 \\
\hline Total & 401 & 100.00 \\
\hline
\end{tabular}

As seen in Table 9, 4.99\% of the respondents sometimes come into contact with intentional damage of their personal belongings done by their students. Normally only $0.50 \%$ and never $76.56 \%$ of the participants. As intentional damage of a teacher's personal belongings at school can be understood, e.g., destruction of a hand-made teaching aid, damaging of their personal possessions, reorganization or creating chaos on the teacher's desk - books, notepads, papers, etc.

Table 10. A learner's effort of a physical attack on a teacher

\begin{tabular}{lcc}
\hline $\begin{array}{c}\text { A learner's effort of } \\
\text { a physical attack on a teacher }\end{array}$ & N & $\%$ \\
\hline never & 380 & 95.00 \\
\hline rarely & 18 & 4.50 \\
\hline sometimes & 2 & 0.50 \\
\hline Total & 400 & $\mathbf{1 0 0 . 0 0}$ \\
\hline
\end{tabular}

Table 11. A real physical attack on a teacher

\begin{tabular}{lcc}
\hline $\begin{array}{c}\text { A real physical attack on } \\
\text { a teacher }\end{array}$ & N & \% \\
\hline never & 384 & 96.00 \\
\hline rarely & 15 & 3.75 \\
\hline sometimes & 1 & 0.25 \\
\hline Total & 400 & $\mathbf{1 0 0 . 0 0}$ \\
\hline
\end{tabular}

Real physical attacks on teachers in Slovak schools hardly ever occur. It is not even about "the real" physical attack - it is more about expressing a learner's dis- 
satisfaction when he/she pulls a book or a pen quickly from the teacher's hands. This study has not revealed any case of physical attacks that should be investigated by the police.

While analysing the results we find that they are within the limits of a certain standard. What is more than certain is the fact that the situation at schools is changing. There are different learners at schools to 30-50 years ago, the world is changing and so are values, educational requirements are increasing, new technologies and globalization are affecting education, and family is changing, etc.

Learners' behaviour is basically similar to the behaviour of learners in other European countries. Negative verbal statements of students and cyberbullying have recently increased. These are the issues that are regularly discussed by Klewin (2006), Wachs, Hess, Shceithauer (2016), and many more authors.

Factors of unacceptable behaviour towards the opposite gender were authenticated by the Mann-Whitney U-test. According to the significance values ( $\mathrm{p}$ > 0.05), we can state that there is no statistically significant difference in factors of inappropriate behaviour between males and females.

Table 12. Unacceptable behaviour based on teachers' gender

\begin{tabular}{|c|c|c|c|c|c|c|c|}
\hline \multicolumn{2}{|c|}{ Gender } & \multirow{2}{*}{$\begin{array}{c}\mathbf{N} \\
332\end{array}$} & \multirow{2}{*}{$\begin{array}{c}\begin{array}{c}\text { An average } \\
\text { order }\end{array} \\
203.13\end{array}$} & \multirow{2}{*}{$\begin{array}{c}\text { Average } \\
6.02\end{array}$} & \multirow{3}{*}{$\begin{array}{c}\text { U-test } \\
10415.500\end{array}$} & \multirow{3}{*}{$\begin{array}{c}\mathrm{Z} \\
-1.009\end{array}$} & \multirow{3}{*}{$\begin{array}{l}\mathrm{p} \text {-value } \\
0.313\end{array}$} \\
\hline negative ver- & female & & & & & & \\
\hline bal statement & male & 68 & 187.67 & 5.60 & & & \\
\hline \multirow[t]{2}{*}{ cyberbullying } & female & 332 & 199.12 & 0.60 & \multirow[b]{2}{*}{10828.500} & \multirow[b]{2}{*}{-0.721} & \multirow[b]{2}{*}{0.471} \\
\hline & male & 68 & 207.26 & 0.60 & & & \\
\hline \multirow{2}{*}{$\begin{array}{l}\text { physical } \\
\text { attack }\end{array}$} & female & 332 & 199.35 & 0.20 & \multirow[b]{2}{*}{10907.500} & \multirow[b]{2}{*}{-0.832} & \multirow[b]{2}{*}{0.405} \\
\hline & male & 68 & 206.10 & 0.21 & & & \\
\hline
\end{tabular}

In our research, we wanted to find out whether there is a difference in the factors of unaccepted behaviour according to the size of schools. We used the Kruskal-Wallis test for three and more independent selections and its result is presented in Table 13. According to the significance value, we can say that the statistically significant difference $(\mathrm{p}<0.05)$ exists only in the factor of negative verbal statement. There is no statistically significant difference in physical attack and cyberbullying ( $>0.05)$. Based on the data about the average order and the average, we can conclude that negative verbal statement is common at schools with fewer than 200 learners and very rare at schools with more than 600 learners (cf., Figure 5). 
Table 13. Unaccepted behaviour according to the size of school

\begin{tabular}{|c|c|c|c|c|c|c|c|}
\hline \multicolumn{2}{|c|}{$\begin{array}{l}\text { Type of unaccepted behaviour and the } \\
\text { size of school }\end{array}$} & \multirow{2}{*}{$\begin{array}{l}\mathrm{N} \\
61 \\
\end{array}$} & \multirow{2}{*}{$\begin{array}{c}\begin{array}{c}\text { An aver- } \\
\text { age order }\end{array} \\
235.78 \\
\end{array}$} & \multirow{2}{*}{$\begin{array}{l}\mathrm{AM} \\
7.33 \\
\end{array}$} & \multirow{2}{*}{$\frac{\mathrm{X} 2}{15.107}$} & \multirow{2}{*}{$\frac{\mathrm{df}}{3}$} & \multirow{2}{*}{$\frac{\text { p-value }}{0.002}$} \\
\hline negative verbal & fewer than 200 learners & & & & & & \\
\hline statement & from 201 to 400 learners & 138 & 214.45 & 6.83 & & & \\
\hline & from 401 to 600 learners & 128 & 182.88 & 5.04 & & & \\
\hline & more than 601 learners & 72 & 172.44 & 4.71 & & & \\
\hline \multirow[t]{4}{*}{ cyberbullying } & fewer than 200 learners & 61 & 217.09 & 0.97 & 5.043 & 3 & 0.169 \\
\hline & from 201 to 400 learners & 138 & 204.45 & 0.54 & & & \\
\hline & from 401 to 600 learners & 128 & 194.01 & 0.61 & & & \\
\hline & more than 601 learners & 72 & 187.64 & 0.39 & & & \\
\hline \multirow[t]{4}{*}{ physical attack } & fewer than 200 learners & 61 & 206.28 & 0.36 & 5.745 & 3 & 0.125 \\
\hline & from 201 to 400 learners & 138 & 206.76 & 0.23 & & & \\
\hline & from 401 to 600 learners & 128 & 196.70 & 0.19 & & & \\
\hline & more than 601 learners & 72 & 187.58 & 0.21 & & & \\
\hline
\end{tabular}

\section{Selected Analysis - Interview with Teachers}

Based on a questionnaire survey, we conducted a structured interview with the teachers of those schools where the teachers filled in the questionnaires. We were focusing on a deeper understanding of the teachers' views on how they perceived pupils' undesirable behavior towards teachers. We are presenting some important findings from the interviews.

1. Do you think that pupils' undesirable behavior in schools has an increasing tendency?

The respondents stated that school pupils' undesirable behavior has an increasing tendency (84.48\%). They consistently stated that the rising tendency is particularly evident in the fact that pupils do not respect the teacher's requirements or instructions. In recent years, teachers' authority has been greatly undermined in schools. Selected responses state, e.g.: Pupils do not appreciate the work of the teacher. Pupils do not appreciate education and it is also manifested in their behaviour; they do not respect the teacher. Pupils' behavior has deteriorated considerably compared to the past. Undesirable behavior does not yet manifest in physical aggression, rather in failure to respect the teacher.

2. What is the cause of pupils' aggravating behaviour in schools? 
The teachers find the causes of the deteriorating state as follows: changes of social conditions (50.00\%), impact of mass media (27.01), demanding curricula (11.49), and inadequate work of teachers (11.50\%). The teachers' views are reflected in such responses as: Social conditions and their manifestations are not a model for young people. Society is dominated by consumer values, it affects the behavior of the youth. Society underestimates school; it does not see school as a place of education and cultivation of pupil's personality. The youth is influenced by the commerciality of the media. The content of education is demanding, teachers do not pay attention to upbringing of pupils. Teachers are assessed based on their teaching outcomes and they pay less attention to upbringing issues.

3. What attention do teachers attach to the emotionality of teaching, which affects the attitudes of pupils to the teacher and their classmates?

Emotionality is becoming more and more appreciated in education. The teachers' views on its application are as follows: Less than half of them think that emotionality is very important (16.57\%), or significantly influential $(27.59 \%)$. However, more than half of them think it is of minor importance $(29.31 \%)$, or has insignificant influence (22.98\%). Some of them cannot judge its importance (3.45\%). The answers show that emotionality in education is not prioritized. Those who appreciate it say: Education without emotionality is not possible. The basis of education is emotionality, and therefore teachers must pay attention to it. Only the teacher who is emotional can also mediate emotions.

In essence, $52.29 \%$ of the respondents believe that teachers are not paying attention to it. They say: The teacher is evaluated according to pupils' learning outcomes, not for their demonstrations of emotionality. Only a small part of teachers interconnects education with upbringing. The lack of emotionality in education is a manifestation of the underestimation of psychology. The teacher pays attention to emotionality only when the pupils' behaviour becomes really bad.

4. What is the impact of teacher's improper (subjective, unfair) assessment of pupils on their behaviour?

Up to $56.90 \%$ of the respondents think this has a large impact, and $21.26 \%$ assign a significant impact to unfair assessment of pupils on their behaviour. The remaining part of the addressed teachers does not consider it as a very important issue. Some of the teachers' statements were as follows: Objective assessment is the basis for a good teacher-pupil interaction. Unfair and subjective assessment does not motivate pupils to learn. It leads to negative attitudes towards the teacher. The fair and objective assessment of pupils contributes to their respect towards their teacher and supports the teacher's authority. The sources of pupils' negative behaviour can often be found in pupils' unfair assessment by teacher(s). 
5. Do you think teachers are well educated to tackle the improper behaviour of their pupils?

Very good readiness to tackle these issues was expressed by $12.64 \%$ of the respondents and good readiness by $17.24 \%$ of them. In total it amounts to $29.88 \%$, which is not a high percentage (less than a third of them). Other respondents, $70.12 \%$, say they are poorly prepared (educated) to solve the more demanding situations in which their pupils' undesirable behavior is manifested. Some of their statements are the following: The best means of resolving undesirable behavior is creative teaching. Teachers are not aware of the methods of shaping social relationships. Teachers try to avoid situations in which they could be confronted with parents; they overlook their pupils' undesirable behavior. In particular, younger teachers are unable to respond to pupils' undesirable behaviour.

6. What kind of violence, do you think, will become increasingly common in schools?

The most common violence will be psychological (43.68\%), cybernetic (39.65), physical $(12.12 \%)$, and other hidden forms of it (4.60\%). The responses of the addressed teachers copy the reality. The teachers' views are as follows: Current electronic media can be exploited for both psychic and cyber-attacks. If society's values are not changed for the better, then we'll have to face different attacks. This can only be improved by a good interaction between school, pupils and teachers. From the point of view of electronics development, it is possible to anticipate the development of cyber-attacks.

7. Do you think the teacher is a decisive factor influencing the pupil's behavior - in particular, the way they manage the educational process?

Up to $94.25 \%$ of the teachers said the teacher was a decision factor, e.g.: The teacher's relationship with pupils determines their mutual relations. The teacher who is a good methodologist, who can motivate pupils and develop their creativity, etc., has no problems with pupils' behavior. What the teacher is like, so are their pupilsthis old truth is still valid today. The teacher must be a model for their pupils, and then they can expect their good behavior.

The interview confirmed that the teachers were very interested in these issues. They are keen to improve the situation in schools and to inhibit unwanted symptoms. Their responses were not only erudite but also emotional.

The respondents share the opinion that the causes of pupils' undesirable behaviour in the education process are often various failures and mistakes in teachers' methodological practices. Learners, particularly in higher grades and secondary schools, express dissatisfaction with the course of lessons and the teacher's demands on their education. 
A serious drawback of education is that teachers do not know their students well and do not apply differentiated approaches to them. Diagnosis of students is not a strong aspect of education.

At school, we communicate less with pupils. Under the influence of the demands on education - more demanding content of education, more demanding requirements on pupils' good knowledge, success in various monitoring tests, and others - the teachers focus primarily on curriculum content and less on learning about their pupils and students, they have little discussion with them, they pay less attention to their behaviour and others. This reduces the quality of pupils' life at school.

Few teachers, not even 50\%, appreciated emotionality. Emotional intelligence must become a foundation in education. According to Goleman (2008), it leads the pupil to:

- being able to express their emotions,

- being able to control their own emotions, but also to influence others,

- being able to motivate themselves and make self-evaluation,

- being empathic, interested in other people,

- being engaged in interpersonal relations.

The respondents' views confirmed that they are in line with Ekman's views and they emphasize in their activities these essential approaches:

- They teach students that emotions vary - the main ones: happiness, sadness, anger, resistance, fear, surprise, but also others, such as: nervousness, frustration, etc.

- Pupils should be taught to control emotions.

- Pupils should be taught how to apply empathy.

- Pupils should be taught to be patient, which leads to success.

- Pupils should be taught to help others.

- Pupils should experience also frustration, which improves their learning and behavior.

- Pupils should be taught to be optimistic and grateful. (Ekman, 2003).

A good teacher, according to Gordon (2003), should follow the following four principles:

1. Learn to listen to others and try to understand what you hear.

2. Learn when it is important to talk with pupils.

3. When dealing with conflicts, no one must feel defeated.

4. It is necessary to establish and maintain an open dialogue with pupils.

In the interview, the teachers accentuated the importance of setting clear requirements for pupils. This applies to both education and upbringing. Without 
this, various "collision relationships" arise between the teacher and the pupil. Teachers can influence pupils' behaviour and reactions based on their approach to learners and the way of working. Good teacher training, interesting content presentation, and good communication with pupils, with stated limits of acceptable behavior, along with the teacher, who serves as an example of creating a positive working atmosphere, will help to prevent undesirable student behavior. The most frequently discussed area in relation to the unwanted manifestations of pupils' behaviour is their evaluation and assessment. Evaluation and assessment have a significant impact on the emotional experiences of pupils, from which their attitudes towards school, teachers and classmates are being developed.

The authors of this paper tend to point out that teachers underestimate self-reflection of their teaching; they do not analyze or critically evaluate their own work enough.

It is always necessary to analyze and look for factors that influence pupils' behavior. The respondents strongly emphasized the correlation between the teacher's work and the student's behavior. The current situation in schools shows that it is not just the failure of pupils, but often also the failure of the teacher. For example, the failure can be caused by the lack of experiences of a novice teacher, the choice of inappropriate educational methods, and wrong approach to pupils, or simply by lapses in the teacher's work. That is why it is necessary to use self-reflection of all kinds of activities (Nolting, 2016).

\section{Conclusion}

The results of our research have confirmed that there are many manifestations of pupils' undesirable behaviour towards teachers in schools. At primary and secondary schools, we did not record problems that need to be addressed by outside school bodies, such as the police. The situation in our schools is comparable to other countries. Schools in all countries report that more than $50 \%$ of schools and teachers have some experiences with pupils' undesirable behaviour. Slovakia does not differ from other countries. In Slovak, schools we can also observe an increase in psychic attacks and cyber-bullying against teachers. The situation is not critical yet, but it requires attention.

However, the most serious and most important are the tasks to stop this growing trend and to establish such authority of the teacher in school as they deserve and as the tradition of good education used to assign to them. Based on our interview 
data analyses, we came up with our own views, which we presented in the paper. The teachers in the interview accentuated the need to improve their work. This reinforces the teacher's authority and pupils' access to education. The findings of our survey will become a starting point for us to create a school prevention program to reduce pupils' undesirable behavior.

\section{References}

Aluede, O., (2006) Bullying in Schools: A Form of Child Abuse in Schools. Educational Research Quarterly. Vol. 30(1), pp.31-39.

Benefield, J., (2004) Teachers - the New Targets of Schoolyard Bullies? [pdf]. Available at http://www.ppta.org.nz/cms/imagelibrary/100894.pdf [Accessed on 8 May 2012].

Dzuka, J., Dalbert, C., (2007) Student Violence against Teachers. Journal of European Psychologist. Vol. 12 (4), pp.253-260.

Ekman, P. (2003) Emotions Revealed. New York : Holt Paperbacks.

Goleman, D. (2008) Emotional intelligence. New York: Bantam Books.

Gordon, T. (2010) Teacher Effectiveness Training. New York: Three River Press.

Helmke, A. (2010) Unterrichtsqualität und Lehrerprofessionalität. Diagnose, Evaluation und Verbesserung des Unterrichts. Seelze: Klett-Kallmeyer.

James, D., Lawlor, M., Flynn, A. et al., (2008) Bullying Behaviour in Secondary Schools: What Roles do Teachers Play? Journal of Child Abuse. Vol. 17, pp.160-173.

Kindler, W., Pőtter, L. (2015). Mobbing gegen Lehrer. Verlag an der Ruther: Mülheim.

Klewin, G. (2006). Alltagstheorien über Schülergewalt. Perspektiven von LehreInnen und SchülerInnen. Wiesbaden: VS-Verlag.

Melzer, W., Schubarth, W., Ehninger, F. (2011) Gewaltprävention und Schulentwicklung Analysen und Handlungskonzepte. Bad Heilbrunn: Verlag Julius Klinfhardt.

Kauppi, T., Pörhölä, M., (2012) School Teachers Bullied by their Students: Teachers' Attributions and how they Share their Experiences. Teaching and Teacher Education. Vol. 28,(7), pp. 1059-1068.

Marini, Z.a., Dane, A.v., Bosacki, S.l. et al., (2006) Direct and Indirect Bully - Victims: Differential Psychosocial Risk Factors Associated with Adolescents Involved in Bullying and Victimisation. Journal of Aggressive Behaviour. Vol. 32, pp. 551-569.

Mooij, T., (2010) Secondary School Teachers' Personal and School Characteristics, Experience of Violence and Perceived Violence Motives. Netherlands: Radboud University Nijmegan.

Nolting, H., P. (2016) Störungen in der Schulklasse: Ein Leitfaden zur Vorbeugung und Konfliklösung. München: Beltz.

Roewer, A. (2017) Das Tabu brechen Gewalt gegen Lehrkräfte. Berlin: VBE.

Scheithauer.h., Bull, H.k. (2009) Aggression und Gewalt an Schulen. In Päd Forum, N. 1, 2009. Berlin.

Speck, O. (1997) Chaos und Autonomie in der Erziehung. München: Verlag E. Reinhardt München. 
Sullivan, K., Cleary, M.. Sullivan, G., (2004) Bullying in Secondary Schools: What It Looks Like and How to Manage It. London: Paul Chapman Publishing.

Wachs, S., Hess, M., Scheithauer, W. (2016). Mobbing an Schulen: Erkennen - Handeln Vorbeugen. Stuttgart: Verlag W. Kohlhammer.

The paper was published within the frame of project KEGA 007KU-4/2017: Devaluatory manifestations of pupils towards teachers - manifestations, causes, prevention. 